\title{
The relationship between free thyroid hormone index and thyrotoxicosis in pregnancy
}

\section{Gebelikte serbest tiroid hormon indeksi ille tirotoksilkoz arasındaki ilişki}

\author{
Fettah Acibucu ${ }^{1}$, Gullsum Uysal ${ }^{2}$, Mehmet Bankir ${ }^{3}$
}

${ }^{1}$ Division of Endocrinology and Metabolism, Department of Internal Medicine, Adana City Research and Education Hospital, Adana, Turkey. ${ }^{2}$ Department of Obstetrics and Gynecology, Adana City Research and Education Hospital, Adana, Turkey. ${ }^{3}$ Department of Internal Medicine, Adana City Research and Education Hospital, Adana, Turkey.

Corresponding author: Gulsum Uysal, MD, Department of Obstetrics and Gynecology, Adana City Research and Education Hospital, Adana, Turkey. E-mail: gulsumaykut@yahoo.com

Received/Accepted: May 06, 2020 /May 13,2020

Conflict of interest: There is not a conflict of interest.

\section{SUMMARY}

Objective: The aim of this study was to evaluate free thyroid hormone index (FTHI) (FT3 index/ FT4 index) as a parameter to use in differential diagnosis of gestational Graves' disease (GGD) and gestational transient thyrotoxicosis (GTT). GGD and GTT are the most common causes of thyrotoxicosis in early pregnancy and differential diagnosis is important since they are treated differently.

Method: Women who applied to our clinic with thyrotoxicosis were evaluated and 51 pregnant women were recruited to the study. Among the 51 women, 36 had GTT, 15 had GGD. The age, gestational age, thyroid stimulating hormone (TSH) levels, and FTHI (FT3 index / FT4 index) of all patients were recorded and compared. FT3/FT3 upper limit of normal (ULN) is referred as FT3 index. FT4 index is also referred as FT4/FT4 ULN. All diagnosis of GGD and GTT was confirmed with TRAb assays.

Results: The mean values of FT3, FT3 index, FTHI of the GGD group were found to be statistically significantly higher compared to GTT group (p: 0.002 , p: 0.001, 0.001; respectively). No statistically significant difference was found between groups in terms of age, gestational age, FT4, FT4 index and TSH (p:0.999, p:0.730, p:0.620, p:0.570, p:0.291; respectively) FTHI values were above 1 in all patients with GGD while it was below 1 in GTT group.

Conclusions: The FTHI values above 1 may be used as a practical, cheap parameter for differential diagnosis between GGD and GTT.

Keywords: Gestational Graves' disease, gestational transient thyrotoxicosis, free thyroid hormone index, parameter.

\author{
Fettah Acrbucu \\ (D) Gulsum Uysal \\ (D) Mehmet Bankir
}

ORCID IDs of the authors: F.A. 0000-0002-2252-2112 G.U. 0000-0002-9381-4892 M.B. 0000-0003-3284-2838

\section{ÖZET}

Amaç: Bu çalışmanın amacı serbest tiroid hormon kat oranları (FTHI) (FT3 index/ FT4 index) kullanılarak gebe hastalarda gestasyonel Graves hastalığı (GGH) ve gestasyonel transient tirotoksikozun (GTT) ayrıcı tanısını yapabilmektir. GGH ve GTT erken gebelikte en sık görülen tirotoksikoz nedenleridir ve farklı şekilde tedavi edildiği için tanıları ayırmak önemlidir.

Yöntem: Kliniğimize tirotoksikozis semptomları ile başvuran kadınların hormonal değerleri incelendi ve çalışmaya 51 gebe alındı. 51 gebenin 36'sında GTT, 15'inde GGH vardı. Tüm hastaların yaş, gebelik yaşı, tiroid stimüle edici hormon (TSH) düzeyleri ve FTHI (FT3 indeksi / FT4 indeksi) kaydedildi ve karşılaştırıldı. FT3 / FT3 normal üst sınırı (ULN) FT3 indeksi olarak adlandırılırken benzer şekilde FT4 indeksi de FT4 / FT4 ULN olarak değerlendirildi. 
Bulgular: GGH grubunun ortalama FT3, FT3 indeksi ve FTHI değerleri GTT grubuna göre istatistiksel olarak anlamlı derecede yüksek bulundu (sırasıyla p: 0.002, p: 0.001, 0.001). Gruplar arasında yaş, gebelik yaşı, FT4, FT4 indeksi ve TSH açısından istatistiksel olarak anlamlı fark bulunmadı (sirasiyla p: 0.999, p: 0.730, p: 0.620, p: 0.570, p: 0.291). GGH'li tüm hastalarda FTHI değerleri 1'in üzerinde iken, GTT grubunda ise 1'in altında idi.

Sonuç: 1'in üzerindeki FTHI değerleri, GGH ve GTT arasında ayırıcı tanı için pratik ve ucuz bir parametre olarak kullanılabilir.

Anahtar sözcükler: Gestasyonel Graves hastalığı, gestasyonel geçici tirotoksikoz, serbest tiroid hormon indeksi, parametre

\section{INTRODUCTION}

Thyrotoxicosis in pregnancy is relatively rare due to the low pregnancy rates and increased pregnancy loss in patients with hyperthyroidism. The average incidence of gestational thyrotoxicosis is about 0.1 $0.4 \%$ and Graves' diseases (GGD) (nearly $85-90 \%$ of all cases) comprises the majority of them ${ }^{1}$. Another common cause of thyrotoxicosis in pregnancy is gestational transient thyrotoxicosis (GTT) which affects up to 2-3\% of pregnancies and is not considered as a disease ${ }^{2}$. In fact, GTT is a biochemical thyrotoxicosis which develops due to the stimulation of TSH receptor by high human chorionic gonadotropin (hCG) in pregnancy ${ }^{2}$. GTT is mostly associated with hyperemesis gravidarum which causes nausea, vomiting, weight loss, dehydration and ketonuria in early pregnancy period ${ }^{3,4}$. Patients with GTT and hyperemesis gravidarum may be hospitalized, if necessary, and administered proper treatment with supportive care for dehydration ${ }^{4}$. GTT which is defined as transient because of hCG, generally recovers by itself until the 20th week of pregnancy ${ }^{5}$. Graves' disease is an autoimmune disease which becomes severe during the early period of pregnancy and severity of GGD decreases depending on the immune suppressive effect of the future pregnancy periods ${ }^{6}$. The autoimmunity is against TSH receptors resulting with TSH receptor antibodies leading to hyperthyroidism ${ }^{7}$. The insufficient control of maternal hyperthyroidism with excessive thyroid hormones is associated with maternal (preeclampsia, heart failure), fetal (abortions, premature labor, stillbirth) and neonatal complications (low birth weight) ${ }^{8}$. These complications may be prevented and alleviated with early and optimal treatment with antithyroid drugs (ATDs) ${ }^{9}$. However, neither ATDs nor any specific medication are recommended for GTT treatment ${ }^{9,10}$. Regarding the risks which may occur in the fetus and the mother due to the different treatment and follow-up, the differential diagnosis of GTT and GGD is important.

In terms of laboratory evaluation, GTT is defined by an elevated serum thyroid hormone levels and low or undetectable serum TSH level in absence of
TRAb. GGD has similar laboratory findings with TRAb positivity.

In this study, we aimed to investigate the serum values of free thyroid hormone index (FTHI) (FT3 index / F4 index) as a cheap routinely used additional parameter besides the serum TRAb titer to differentiate GTT and GGD.

\section{MATERIAL AND METHODS}

This present study was conducted between December 2015 and June 2016 at XXXX Training and Research Hospital, Sivas, Turkey. Informed written consent was obtained from all participants. The study was approved by the local ethics committee of the university (Number 2015-10/09).

\section{Patient selection and study design:}

Referred pregnant patients (before 20 weeks of gestation) with low TSH values $\left(<0.1 \mu \mathrm{IU} / \mathrm{ml}\right.$ in $1^{\text {st }}$ trimester and $<0.2 \mu \mathrm{IU} / \mathrm{ml}$ in the $2^{\text {nd }}$ trimester of pregnancy), with free $\mathrm{T} 4$ and/or T3 levels that exceed trimester specific normal reference ranges diagnosed as overt hyperthyroidism were included to the study. Patients who were diagnosed with GTT and GGD comprised study groups. The age, gestational age (week), free T3 (FT3), free T4 (FT4), (TSH), FT3 index (FT3/FT3 upper limit of normal (ULN), FT4 index (FT4/FT4 ULN) and FTHI (FT3 index / FT4 index) were recorded. The all values above were compared between the groups. FTHI and other tests were also evaluated in eligible non-pregnant patients, in case of detecting and comparing normal ranges without pregnancy due to the low number of GGD.

GTT was defined as low or undetectable TSH, high free thyroid hormone levels in first or early second trimester with normal TRAb level ${ }^{11-13}$. Generally, these patients had no symptoms or symptoms like hyperemesis gravidarum with absence of clinical findings of GGD. Moreover, they had no history of hyperthyroidism before pregnancy.

Patients with low or undetectable TSH, high free thyroid hormone levels in first or early second trimester with high TRAb level with presence of 
clinical findings (tremor, palpitation, etc.) or physical findings such as thyroid enlargement or exophthalmos were diagnosed GGD 11-13. All diagnosis of GGD and GTT was confirmed with $\mathrm{TRAb}$ assays and clinical follow during the pregnancy.

Multiple pregnancies, patients with destructive thyroiditis or other reasons of hyperthyroidism, history of thyroid surgery, radioactive iodine ablation therapy, history of radiation exposure to the neck and patients who had been treated with drugs that alter thyroid functions at the time of the blood tests were excluded.

Eventually, a total of 177 women newly diagnosed with thyrotoxicosis were found to be eligible for the whole study. Of these 177 cases, 51 cases were pregnant and comprised study group. Remaining of 126 were included in non-pregnant GD group to check the values in non-pregnant cases due to low number of GGD.

\section{Hormone assays and statistical analysis:}

Serum samples of all patients were collected after an overnight fast and sent immediately for laboratory assessment on the day of admission. Serum FT3, FT4 and TSH levels were measured by the chemiluminescent immunoassay using Beckman Coulter DxI 800 immune-analyzer with original reagents.

The clinical features of both groups were compared with the Statistical Package for Social Sciences
(SPSS) for Windows, version 22.0 (SPSS Inc. IL, USA). Normality of data distribution was tested with Kolmogorov-Smirnov test. Data was presented as means \pm SD for continuous variables. We used median for nonparametric variables and showed minimum-maximum levels. To assess the differences in variables between groups, the independent $t$ test was used. Values of $p<0.05$ was accepted as statistically significant.

\section{RESULTS}

There were 51 pregnant patients recruited for the study. Among the 51 women, 36 had GTT, 15 had GGD. The maternal age, gestational age and laboratory features of the patients in groups were shown in Table 1. No statistically significant difference was found between groups in terms of age, gestational age, FT4, FT4 index and TSH (p:0.999, p:0.730, p:0.620, p:0.570, p:0.291; respectively) (Table 1). Values of FT3 and FT3 index were found to be statistically significantly higher in GGD group (p:0.002, p:0.001, respectively), however no differentiating threshold was found.

FTHI values were showed in Figure 1. FTHI was also found to be statistically significantly higher in GGD group especially above 1 in all pregnant patients. It was below 1 in all patients in GTT group. Additionally, FTHI was found to be above 1 (slightly lower than GGD) in all nonpregnant Graves patients (Figure 1).

Table 1: Comparision of maternal and gestational age and laboratory values of groups.

\begin{tabular}{|l|l|l|l|}
\hline & GGD & GTT & P value \\
& $\begin{array}{l}\text { N=15 } \\
\text { mean } \pm \text { SD }\end{array}$ & mean \pm SD & \\
\hline Age (year) & $27.20 \pm 14.04$ & $27.33 \pm 4.87$ & 0.999 \\
\hline $\begin{array}{l}\text { Gestational age(week) } \\
\text { Median (min-max) }\end{array}$ & $12(6-20)$ & $10.5(5-16)$ & 0.730 \\
\hline FT3 (pg/mL) & $10.57 \pm 8.23$ & $4.74 \pm 1.35$ & 0.002 \\
\hline FT3I & $2.40 \pm 1.87$ & $1.06 \pm 0.31$ & 0.001 \\
\hline FT4 (ng/dl) & $2.37 \pm 1.68$ & $2.06 \pm 0.56$ & 0.620 \\
\hline FT4I & $1.39 \pm 0.99$ & $1.21 \pm 0.33$ & 0.570 \\
\hline TSH $(\mu \mathrm{IU} / \mathrm{ml})$ & $0.01 \pm 0.01$ & $0.02 \pm 0.02$ & 0.291 \\
\hline FTHI & $1.72 \pm 0.87$ & $0.87 \pm 0.07$ & 0.001 \\
\hline
\end{tabular}

GGD: Gestational Graves' disease, GTT: Gestational transient thyrotoxicosis, FT3: free T3, FT3I: FT3 index, FT4: free T4, FT4I: FT4 index, TSH: Thyroid stimulating hormone, FTHI: Free thyroid hormone index, Min: Minimum, Max: Maximum, SD: Standart Deviation. 


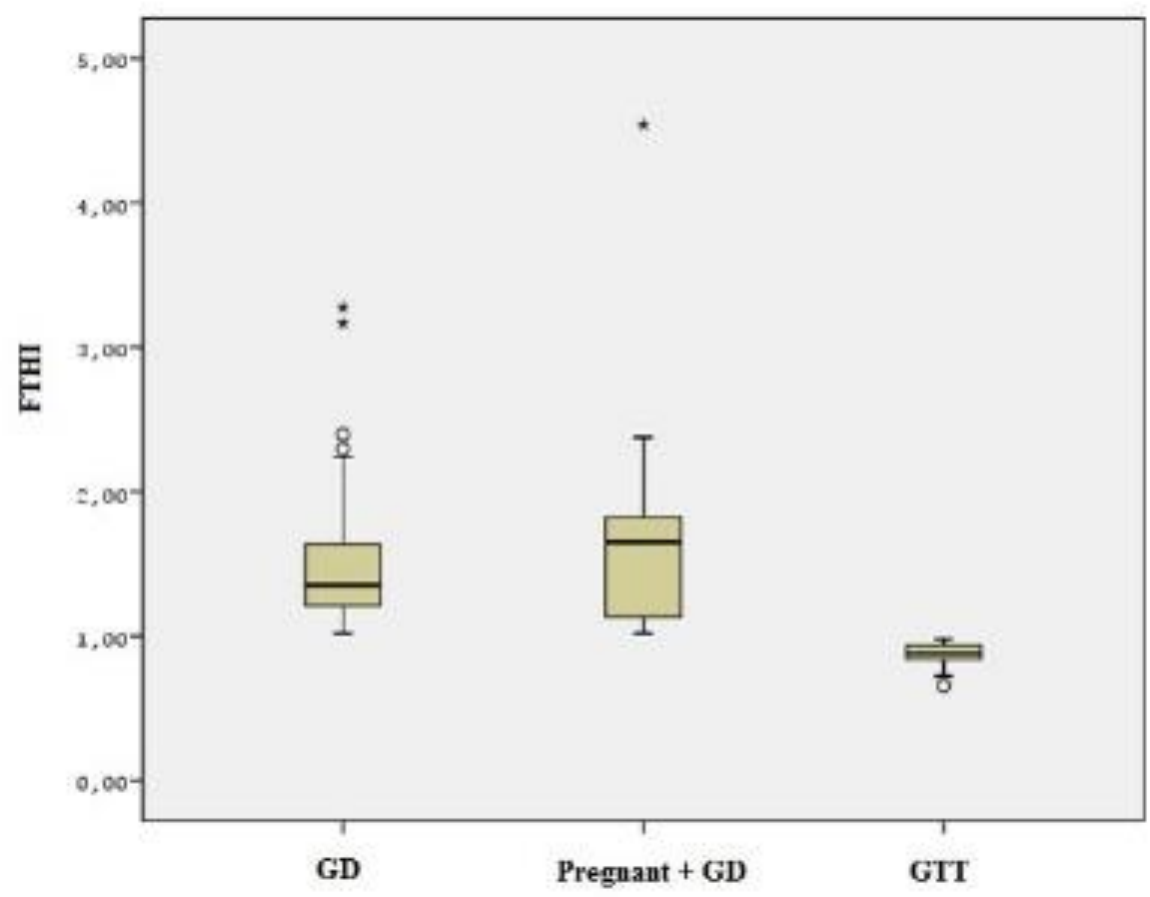

Figure 1: Comparison of groups according to free thyroid hormone index (FTHI)

Table 2: The features of nonpregnant patients with GD.

\begin{tabular}{|l|l|}
\hline & $\begin{array}{l}\text { Non-pregnant GD } \\
\text { mean } \pm \text { SD n }=126\end{array}$ \\
\hline Age (year) & $38.95 \pm 14.04$ \\
\hline FT3 $(\mathrm{pg} / \mathrm{mL})$ & $12.24 \pm 6.81$ \\
\hline FT3I & $2.76 \pm 1.51$ \\
\hline FT4 $(\mathrm{ng} / \mathrm{dl})$ & $3.24 \pm 1.72$ \\
\hline FT4I & $1.91 \pm 1.01$ \\
\hline TSH $(\mu \mathrm{IU} / \mathrm{ml})$ & $0.01 \pm 0.01$ \\
\hline FTHI & $1.46 \pm 0.37$ \\
\hline
\end{tabular}

GD: Graves' disease, FT3: free T3, FT3I: FT3 index, FT4: free T4, FT4I: FT4 index, TSH: Thyroid stimulating hormone, FTHI: Free thyroid hormone index, Min: Minimum, SD: Standart Deviation.

The features of nonpregnant patients with GD were summarized in Table 2. The mean age of nonpregnant GD patients was higher than pregnant patients. Except for TSH and FTHI all other values of thyroid indices were slightly higher than GGD group.

None of the women had a hydatidiform mole or choriocarcinoma.

\section{DISCUSSION}

This study reports that FTHI (FT3 index / FT4 index) may be used to differentiate GGD and GTT in the early period of pregnancy especially in places where TRAb assays are not widely available or routinely used because of expensive costs. To our knowledge this is the first study that FTHI is used to distinguish diagnosis of GGD and GTT and is original. 
It is well known that the most common causes of hyperthyroidism in pregnancy are Graves' disease and GTT ${ }^{7}$. Regarding fetal risks, treatment and follow-up periods the differential diagnosis of GTT and GGD is important both for clinicians and patients ${ }^{2}$. A careful history and physical examination is vital in distinguishing the etiology. Although nonspecific symptoms of hyperthyroidism may occur during pregnancy, palpitation, anxiety, tremor in hands and heat intolerance are common clinical findings of both conditions ${ }^{13}$. The presence of orbitopathy suggests GGD, however severe orbitopathy in women under the age of 40 is very rare ${ }^{14}$. In the absence of clinical features and to confirm the exact diagnosis, laboratory tests are routinely used. The TRAb assays are performed to make the differential diagnosis between GGD and GTT when investigating hyperthyroidism of uncertain etiology, including thyrotoxicosis associated with hyperemesis gravidarum ${ }^{13,15}$. Unfortunately, long time and high costs are needed to get results of this highly sensitive and specific TRAb tests. Moreover, these assays are not available in many clinics. Therefore, we attempt to use this FHTI to differential diagnosis between GGD and GTT.

Park et al., ${ }^{16}$ investigated the association of TSH, FT4, FT3, and metabolic parameters and found that higher FT3/FT4 ratio was associated with increased risk of metabolic syndrome parameters and insulin resistance. They also mentioned that the FT3/FT4 ratio was good predictive parameter in metabolic syndrome. In another study, Yoshihara et al. ${ }^{17}$ evaluated serum hCG as a parameter for differentiating between active Graves' disease (GGD) and GTT. They reviewed 135 cases (103 GTT, 32 GGD) during 7th to 14th week of pregnancy and showed that serum hCG level of the GTT group was significantly higher than in the active GGD group, but it was not a good parameter for differentiating between the two groups. They also revealed that the FT3/FT4 ratio of the active GGD was significantly higher than in GTT group, and a better parameter for differentiation ${ }^{17}$. In addition, Tagami et al., ${ }^{18}$ evaluated serum FT3/FT4 ratio of GGD patients and found higher values compared to GTT group.

In our study, it was aimed to obtain how much serum FT3 and FT4 increased compared to their ULN and aimed to find the ratio of these increases. Therefore, we used index of hormones in this study as a parameter. Moreover, a significant difference between the groups in terms of FT3 and FT3 index was found, but there were no thresholds to distinguish the diseases. FT3 index increased more than FT4 and FTHI was $>1$ in patients diagnosed with GGD during pregnancy. In Graves' disease, there is higher T3 production from the thyroid gland and serum T3 and free T3 levels are found to be increased compared to serum $\mathrm{T} 4$ and free $\mathrm{T} 4$ levels ${ }^{19}$. This may be an explanation of our results. On the other hand, GTT is generally associated with hyperemesis and there is T4 thyrotoxicosis, particularly ${ }^{20}$. As mentioned above, the increase of T3 is more than T4 in GGD and that the increase of T4 is higher in GTT, however the extent of this increase has not been established yet.

Due to the low number of patients diagnosed with GGD in our study, we also evaluated these rates in non-pregnant GD patients. Similarly, in GGD group, FTHI was found to be above 1 in nonpregnant GD patients. This situation supported our results. Except for TSH and FTHI all other values of thyroid indices were slightly higher than GGD group. The physiological changes in pregnancy and immunosuppressive effect may be the reason of this result.

There are several limitations in this study. First, the numbers of each group were small. Secondly, the serum hormone index was measured only once in every subject and was not compared after treatment or in third trimester of pregnancy.

Nevertheless, the current study has definitive strengths. First, to our knowledge, this study was the first to the distinguish the diagnosis of GGD and GTT by using FHTI (FT3 index/FT4 index).

In conclusion, only controlling the increase rates in free thyroid hormones by using FHTI (FT3 index/FT4 index), the differential diagnosis of GGD and GTT can be distinguished. Since FTHI can be estimated from routine free hormones, it is widely available. The FTHI values may be used as a practical, cheap parameter for differential diagnosis between GGD and GTT.

\section{Acknowledgments: None}

Conflict of interest: No potential conflict of interest relevant to this article was reported.

Funding: None

\section{REFERENCES}

1. Krassas GE, Poppe K, Glinoer D. Thyroid function and human reproductive health. Endocr Rev 2010; 31: 702-55.

2. Galofre JC, Davies TF. Autoimmune thyroid disease in pregnancy: a review. $\mathbf{J}$ Womens Health (Larchmt) 2009; 18: 1847-56. 
3. Niebyl JR. Clinical practice. Nausea and vomiting in pregnancy. $\mathrm{N}$ Engl $\mathrm{J}$ Med 2010; 16: 1544-50.

4. Verberg MF, Gillott DJ, Al-Fardan N, Grudzinskas JG. Hyperemesis gravidarum, a literature review. Hum Reprod Update 2005; 11: 527-39.

5. Gharib H, Tuttle RM, Baskin HJ, Fish LH, Singer PA, McDermott MT. Subclinical thyroid dysfunction: A joint statement on management from the American Association of Clinical Endocrinologists, the American Thyroid Association, and The Endocrine Society. J Clin Endocrinol Metab 2005; 90: 586-7.

6. Grigoriu $\mathrm{C}$, Cezar $\mathrm{C}$, Grigoras $\mathrm{M}$, Horhoianu I, Parau C, Vîrtej P, Lungu A, Horhoianu V, Poiana C. Management of hyperthyroidism in pregnancy. J Med Life 2008; 1: 390-6.

7. David S Cooper, Peter Laurberg. Hyperthyroidism in pregnancy. Lancet Diabetes Endocrinol 2013; 1: 238-49.

8. Luewan $S$, Chakkabut $P$, Tongsong $T$. Outcomes of pregnancy complicated with hyperthyroidism:a cohort study. Arch Gynecol Obstet 2011; 283: 243-7.

9. Poppe K, Hubalewska-Dydejczyk A, Laurberg P, Negro R, Vermiglio F, Vaidya B. Management of Hyperthyroidism in Pregnancy: Results of a Survey among Members of the European Thyroid Association. Eur Thyroid J 2012 ; 1: 34-40.

10. Alamdari S, Azizi F, Delshad H, Sarvghadi F, Amouzegar A, Mehran L. Management of hyperthyroidism in pregnancy: comparison of recommendations of american thyroid association and endocrine society. J Thyroid Res 2013; 2013: 878467.

11. Goodwin TM, Montoro M, Mestman JH. Transient hyperthyroidism and hyperemesis gravidarum: clinical aspects. Am J Obstet Gynecol 1992; 167: 648-52.

12. Tan JY, Loh KC, Yeo GS, Chee YC. Transient hyperthyroidism of hyperemesis gravidarum. BJOG 2002; 109: 683-8.

13. Stagnaro-Green A, Abalovich $M$, Alexander E, Azizi F, Mestman J, Negro $R$, Nixon A, Pearce EN, Soldin OP, Sullivan S, Wiersinga W; American Thyroid Association Taskforce on Thyroid Disease During Pregnancy and
Postpartum. Guidelines of the American Thyroid Association for the diagnosis and management of thyroid disease during pregnancy and postpartum. Thyroid 2011; 21:1081-125.

14. Laurberg $P$, Berman DC, Bülow Pedersen I, Andersen S, Carlé A. Incidence and clinical presentation of moderate to severe graves' orbitopathy in a Danish population before and after iodine fortification of salt. J Clin Endocrinol Metab 2012; 97: 232532.

15. Matthews DC, Syed AA. The role of TSH receptor antibodies in the management of Graves' disease. Eur J Intern Med 2011; 22: 213-6.

16. Park SY, Park SE, Jung SW, Jin HS, Park IB, Ahn SV, Lee S. Free triiodothyronine/free thyroxine ratio rather than thyrotropin is more associated with metabolic parameters in healthy euthyroid adult subjects. Clin Endocrinol (Oxf) 2017; 87: 87-96.

17. Yoshihara A, Noh JY, Mukasa K, Suzuki M, Ohye $\mathrm{H}$, Matsumoto M, Kunii Y, Watanabe N, Suzuki N, Kameda T, Sugino $\mathrm{K}$, Ito K. Serum human chorionic gonadotropin levels and thyroid hormone levels in gestational transient thyrotoxicosis: Is the serum hCG level useful for differentiating between active Graves' disease and GTT? Endocr J. 2015; 62: 557-60.

18. Tagami $T$, Hagiwara $H$, Kimura $T$, Usui $T$, Shimatsu A, Naruse M. The incidence of gestational hyperthyroidism and postpartum thyroiditis in treated patients with Graves' disease. Thyroid 2007; 17 : 767-72.

19. Laurberg $P$, Vestergaard $H$, Nielsen $S$, Christensen SE, Seefeldt T, Helleberg K, Pedersen KM. Sources of circulating 3,5,3'-triiodothyronine in hyperthyroidism estimated after blocking of type 1 and type 2 iodothyronine deiodinases. J Clin Endocrinol Metab 2007; 92: 2149-56.

20. Goldman AM, Mestman JH. Transient non-autoimmune hyperthyroidism of early pregnancy. J Thyroid Res 2011; 2011: 142413. 